\title{
Scenes from the Class Struggle in Picture Books: Depictions of Housing and Home in Books for Young Children
}

\author{
Vikki C. Terrile ${ }^{1} \mathbb{D}$
}

Accepted: 15 June 2021 / Published online: 1 July 2021

(c) The Author(s), under exclusive licence to Springer Nature B.V. 2021

\begin{abstract}
While there is still much to be done, there have been tremendous strides made in increasing the diversity of children's literature; however one area that is often overlooked in these conversations is social class. From years of providing picture book story time to young children living in homeless shelters, it became obvious that picture books being published in the U.S. privilege the experiences of middleand upper-class people, especially in their depictions of home and housing. Based on analysis of 185 picture books published in the U.S. between 1999 and 2019, I argue that home as typically represented in children's picture books presents a limited and privileged view that normalizes single-family homes, material possessions, and related middle-class experiences. Further, these books do not reflect the lived experience of the millions of American children in the United States experiencing homelessness and housing instability, as well as those who live in apartments, trailers and other types of homes that contemporary picture books would have us believe do not exist.
\end{abstract}

Keywords Picture books $\cdot$ Home $\cdot$ Homelessness $\cdot$ Socioeconomic status $\cdot$ Class

Watching a child connect with a book recommended by a teacher or librarian is deeply gratifying. We understand the need of children to see themselves and their

\footnotetext{
Vikki C. Terrile is an Assistant Professor at Queensborough Community College, the City University of New York (CUNY) where she serves as the Public Services and Assessment Librarian and Co-Coordinator of Information Literacy. Vikki earned her BA in English from Wells College, her MS in library science from Long Island University, her MA in urban affairs from Queens College (CUNY), and is currently a doctoral student in education at SUNY, the University at Buffalo. Her research interests include the literacy practices of children and parents experiencing homelessness, the information behaviors of Renaissance Faire performers and artisans, and the role of academic libraries in addressing student food and housing insecurity. Vikki is currently exploring how librarians understand their work with families experiencing homelessness.
}

Vikki C. Terrile

vterrile@qcc.cuny.edu

1 Queensborough Community College (Library), Bayside, NY, USA 
families depicted with respect and accuracy in the books to which they are exposed, and while there is still much to be done, there have been tremendous strides made in increasing the diversity of children's literature. One area that is often overlooked in the conversations about diversity, equity, and inclusion is social class, perhaps because Americans are still uncomfortable with the idea that we live in a classed society (Pascale, 2005), perhaps because socioeconomic class is often entwined problematically with race and ethnicity (Jones, 2008). In this context, children's picture books, like so much of mainstream U.S. culture, often present subtle but pervasive messages that normalize middle- and upper-class experiences while virtually ignoring those of people from working-class and lower-income backgrounds. This privileging of some lived experiences over others is ideologically troubling, but also has serious consequences in practice. As Rudine Sims Bishop (1990) argued,

When children cannot find themselves reflected in the books they read, or when the images they see are distorted, negative, or laughable, they learn a powerful lesson about how they are devalued in the society of which they are a part (para. 4).

Too often, books that address issues related to class or socioeconomic status, are relegated to "problem" books, often with a moral or solution (Kelley and Darragh, 2011).

According to Lawrence R. Sipe (2011), "One of the aspects of the art of the picturebook that we must address, therefore, is how the modes of representation in picturebooks are necessarily freighted with sociocultural and political significance" (p. 244). While Sipe addresses race, ethnicity, gender, and sexuality, he does not mention socioeconomic class as an area of needed diversity of representation in picture books for children. Similarly, Perry Nodelman and Mavis Reimer (2003) explain that

Picture books both depend on and teach such conventional assumptions. Simply by depicting details to be taken for granted, they provide young viewers with ideas and attitudes about matters such as beauty and ugliness, cleanliness and filth, and vice and virtue, and confirm ideas about normality that may or may not be desirable (p. 288).

Thus, books for young children that include images or narratives around poverty, social class, hunger, or homelessness may replicate widespread culture messages about deservedness, work, and capitalism. Because of this, "Children reading these books may gain the misunderstanding that middle- and upper-class families are the norm, and that all people who are poor do not know how to manage their money" (Kelley and Darragh, 2011, p. 266).

Perhaps the most obvious way that picture books reproduce class assumptions is in their depictions of house and home. Over many years sharing picture book story times with preschool children living with their families in homeless shelters, I was intentional in my selection of books so that the kids could see characters who looked like them. People of color are vastly overrepresented among those who are unhoused (de Bradley, 2015); thus I looked for picture books with 
Black and Latinx characters as much as possible. Eventually, even in books with diverse characters, I noticed how common things like vacations and trips, backyard swimming pools, and huge bedrooms cluttered with clothes and toys were in picture book illustrations and became increasingly careful about not including books that featured these things, as well. I began to recognize that most picture books featured large, single-family homes, spacious private bedrooms, and an array of other signifiers of class status vastly different from the lived experiences of the children in my programs. At the same time, I started to reflect on my own experiences as a reader of books for children and recalled just two times when I recognized my childhood class experiences in a book. Even now I can recall a book I read as a child where the family had no living room furniture because the mother had yet to decide on it for their new home; we also did not have living room furniture but because we could not afford it, and this shared experience with the story has stayed with me for decades, imperfect as it is. I was an adult the first time I read a book for young people where the characters had socioeconomic class circumstances similar to mine as a child (Sara Zarr's Story of a Girl) and had a visceral response to reading a setting that felt familiar. Based on these experiences, I designed a formal study to uncover what images of home children in the United States are exposed to through picture books.

Using the Marantz Picturebook Collection for the Study of Picturebook Art in the Reinberger Children's Library Center at Kent State University, ${ }^{1}$ I explored representations of home in 150 picture books published from 1999 to 2015 . To complete the study in 2020, I read and reviewed an additional 35 picture books published between 2015 and 2019. Based on my outreach work and my long experience as a librarian, I speculated that picture books published (originally or in translation) and sold in the United States would privilege representations of home that signify middle class experiences, including single-family dwellings, yards, private bedrooms, and large spaces. The books studied during the Albers Fellowship support this: 91 (83\%) of the 110 books that feature a home in any way show clear evidence in their illustrations that home is a single-family dwelling. The more recent books also follow this pattern, although to a lesser extent: 15 (54\%) of the 28 books featuring some sort of home depict a single-family residence. Thus, I argue that home as typically represented in children's picture books presents a limited and privileged view that normalizes middle-class experiences, and does not reflect the lived experience of the millions of American children who live in apartments, trailers and other types of homes, as well as those children experiencing homelessness and housing instability.

\footnotetext{
${ }^{1}$ Most of the research for this study was conducted through the first Jacqueline M. Albers Guest Scholar in Children's Literature Fellowship at Kent State University, which I received in 2015.
} 


\section{The Study}

The purpose of this research was to examine a sample of picture books published from 2000 to 2020 and widely available in the U.S. to determine how home is represented in these works. The assumption was that in most cases, home settings would be just that, settings that were not necessarily integral to the story but took up significant visual space in the illustrations. These settings are often ancillary to the words and story and therefore left to the illustrator's imaginings. As children read or are read picture books, the pictures play a significant role in their understanding of the story's world. As Nodelman and Reimer (2003) explain,

everything in such pictures is less important as a source of aesthetic delight than as a source of information about a story. However pleasing they are, their shape, their style, their composition are also means of conveying information about how viewers are being invited to respond to the story (p. 277).

As the results of the study show, what viewers are invited to respond to in most picture books are home settings that are decidedly middle-class and feature material possessions that reflect particular class signifiers and norms.

The picture books studied were culled from a list that included winners and honor books from the following awards from 2000 to 2015: Caldecott, Coretta Scott King (illustrator), Ezra Jack Keats (writer and illustrator), Golden Kite (picture book text and picture book illustration), Boston Globe-Horn Book, Wanda Gág Read Aloud, Pura Belpré (illustrator). In addition, I included starred picture book reviews from School Library Journal for the first half of 2015, as well as ALSC's Notable Books for Younger Readers for 2014 and 2015. While the goal was to review only picture books, a few early readers in picture book-like format were included as they had received notice as picture books. This resulted in a list of 336 unique titles. I opted to include all of the Caldecott Medal winners and honor books and the Wanda Gág Read Aloud books on my list of books to review since these titles are more likely to be introduced to children in school and library settings based on their recommendations from the awards. I also added the Boston Globe-Horn Book winners to the list on the assumption that those might have some level of popular appeal to parents and other caregivers. In addition, I included books that seemed likely to offer depictions of home based on their titles (i.e. reference to mowing a lawn, chairs, and family relationships). Using these criteria, I had a sample of 133 books to review. Finally, I sorted the remaining list of 203 titles by illustrator, numbered them in order from 1 to 203 and used an online random number generator to randomize the list of numbers. I reassigned each of the remaining titles the corresponding randomized number and re-sorted the list based on their randomly assigned number. I then included the first 42 books on that list to complete a list of 175 books, with the goal to physically review 150 books, assuming not all of the titles would be available in the Marantz collection.

For books published between 2015 and 2019, I used a similar strategy, collecting the winners and honor books from the following awards during those 
years: Caldecott, Coretta Scott King (illustrator), Ezra Jack Keats (writer and illustrator), Golden Kite (picture book text and picture book illustration), Boston Globe-Horn Book, Wanda Gág Read Aloud, Pura Belpré (illustrator), a list of 149 unique books. The original review list was created in the same way as the list for the Albers fellowship, prioritizing the same awards and randomizing the remainder of the list to obtain a booklist of 50 titles. Unfortunately, the COVID-19 pandemic necessitated a change in procedure. I was able to read and review ten print books from the list of 50 before New York City public libraries closed for the pandemic (I had six additional titles on hold at the time of the closure). Only nine of the remaining 40 books were available as e-books from the public library and those were reviewed in digital format. However, in order to reach a reasonable sample, I went back to the original list of 149 books, and checked for digital availability. Subsequently, I was able to review ten more titles as e-books from the public library; six additional books were selected at random and purchased in print format for a total sample of 35 books. Because there are so few books that depict childhood homelessness, I also reviewed three books ${ }^{2}$ that feature families in homeless situations and will discuss them separately.

To determine if the books featured home as a setting and to determine further the type of dwelling, the illustrations were examined for indicators. These included exterior views of the dwelling, the inclusion of a yard or other outdoor space around the dwelling, as well as interior spaces, specifically individual rooms and furnishings. If there were illustrations of interior spaces that signified home but not clear indicators of the type of dwelling, those spaces were counted as having a home setting but not as being single-family. In addition to determining the type of home featured in the illustrations, I also looked for indicators of class status including the presence and abundance of material objects such as toys, clothes, books, decorations, and artwork in the interiors (Sano, 2009). It should also be acknowledged that in the vast majority of these books, home was a setting that was not particularly important to the development of the story; the rooms and material possessions were background, part of the books' landscapes.

Using these methods, I found that of the 185 picture books analyzed, 138 (74.59\%) feature some type of depiction of house or home. Whether the main characters are human or animal, home as a setting was common: of 114 books with human characters, $96(84.21 \%)$ depict house or home; of 33 books with animal main characters, $22(66.67 \%)$ include homes; of the 34 books where the main characters are both human and animal, $19(55.88 \%)$ show house or home. For animal characters, the homes that are illustrated are often anthropomorphized spaces with rooms, furnishings, and decorations rather than realistic animal homes (nests, dens, burrows, etc.), adding to the normalizing of middle-class homes within the context of picture book illustration. In the four books where the main characters are identified as "other" than human or animal (a punctuation mark, a mythic creature, an anthropomorphized cake, and animate vegetables), only one has a home depicted, but it

\footnotetext{
2 The most well-known picture book about family homeless, Fly Away Home by Eve Bunting, illustrated by Ronald Himler, was published in 1991 and is thus outside the scope of this research.
} 
is unclear if this is a single-family or other type of dwelling. The majority of the picture books in this sample (106 or $76.81 \%$ of those that featured a home) feature homes that appear to be single-family dwellings based on signifiers including the architecture of the house and/or the presence of a yard or other open outdoor space separating the house from other buildings. Of the 32 books that feature homes that are not obviously single-family, 13 feature homes that are identifiable as apartments and two feature homes that are trailers. For the 17 remaining books, the illustrations and textual cues do not provide enough information to determine what type of dwelling is being depicted.

\section{The Nature of Housing and Home}

To better understand why diverse representations of home are needed in books for young children, we need to understand where children call home in real life. Many young children live in stable home environments that are not single-family homes. According to Census data, $61 \%$ of housing units in the United States were detached, single-family dwellings in 2018 (United States Census Bureau). The remaining $39 \%$ of units included attached homes, apartments/condos/co-ops, mobile homes, and boats, RVs, and vans. Yet, as we will see, these types of dwellings are depicted infrequently in books for children, and when they are, are often illustrated in ways that are more reminiscent of a single-family home than the type of unit they are. Additionally, homelessness and housing instability impact preschool aged children at higher rates than any other group of children. According to the National Center for Children in Poverty (NCCP), "Research is clear that poverty is the single greatest threat to children's well-being" (n.d.). That the families of $43 \%$ of American children are low-income, including $21 \%$ of children who live with their families below the federal poverty level (NCCP) is deeply concerning. One way that poverty impacts children's lives is through housing instability and homelessness. Housing instability can be "defined as having difficulty paying rent, spending more than $50 \%$ of household income on housing, having frequent moves, living in overcrowded conditions, or doubling up with friends and relatives" (Kushel et al., 2006, p. 71). Poverty is highly correlated with housing instability, although determining the number of Americans who experience unstable housing has proved challenging (Frederick et al., 2014). As defined by various federal laws, being homeless means lacking "fixed, regular, and adequate nighttime residence" (USC02) and includes those living in shelters, doubled up with family or friends, ${ }^{3}$ living in motels or campgrounds, in cars or on the street or public spaces. As of 2014, homelessness among American children had reached an all-time high, with nearly 2.5 million children (or 1 in 30) experiencing homelessness at some point in their childhood (America's Youngest

\footnotetext{
${ }^{3}$ Living in a doubled-up situation falls under the definition of homelessness in the McKinney-Vento Act, which mandates educational protections for school-age children and youth, but is not typically considered homeless by the United States Department of Housing and Urban Development (HUD) and other agencies.
} 
Outcasts). Of particular concern to the study of picture books is the awareness that at least half of the population of children who experience homelessness are under the age of six (Child Trends). Ralph da Costa Nunez (2010) argues that the lack of commitment to low-income or affordable housing in the United States has created a situation where for many young children "for the duration of their childhoods, a shelter may be their only home" (p. 1). These circumstances are sociopolitical as well as being socioeconomic; thus, the collective discomfort of viewing shelters, overcrowded apartments, trailers, motels, or campgrounds as "home" contests the reality that they are for millions of children.

Developmentally, a stable home is considered a basic need, part of the foundational necessities that allow humans to develop relationships, self-worth, and ultimately self-actualization (Maslow, 1954). In American culture, home is intrinsically linked to positive feelings of safety and stability, perhaps best illustrated by the well-known and beloved quote from the movie The Wizard of $\mathrm{Oz}$ (1939), "there's no place like home." Matthew Desmond (2016), in his seminal work on eviction, makes several claims about the importance of stable and secure homes that are in line with these cultural norms and assumptions about home, arrived at as the result of his research and experiences around housing instability in Milwaukee, Wisconsin. He points out that

The home is the center of life. It is a refuge from the grind of work, the pressure of school, and the menace of the streets... The home is the wellspring of personhood. It is where our identity takes root and blossoms...In languages spoken all over the world, the word for "home" encompasses not just shelter but warmth, safety, family - the womb...America is supposed to be a place where you can better yourself, your family, and your community. But this is only possible if you have a stable home. (Desmond, 2016, pp. 293-294)

Clearly, these comments are meant to support Desmond's policy recommendations around eviction protections and other strategies to keep low-income residents in their homes. That some people who lack the stability and safety of home in childhood are able to have success and stability as adults is obvious. At the same time, there is abundant evidence that the social and cultural capital of privilege make academic and career success much more likely. This becomes a slippery slope; we lionize stable middle-class home and family, demean those who are poor or working-class, and glorify examples of rugged individuals who pulled themselves up by their bootstraps and completed their rags to riches stories. Poverty and homelessness thus become personal obstacles to overcome, rather than systemic forces to be dismantled.

These messages are often reproduced in literature for children. In their study of homelessness in American picture books, Jinhee Kim and Su-Jeong Wee (2020) observe that "The analysis showed that homelessness was described as a personal choice and individual responsibility rather than as being determined by sociopolitical circumstances" (p. 372). However, the authors continue with a problematic point: "The characters were described as inferior or passive subjects who needed and received help, rather than as active beings who tried to work hard to escape their difficult situations" (p. 372). This notion that hard work is enough to "escape" homelessness, which the authors have already framed as the result of "sociopolitical 
circumstances" perpetuates the very idea they seem to argue against in the first point. Examining how poverty is depicted in picture books, Jane E. Kelley and Janine J. Darragh (2011) observe that most of the books feature some type of action, and note that,

While it is good to see portrayals of individuals enacting change, this does have potential for being problematic as it can reinforce the notion that people can pull themselves up by their bootstraps, and that poverty is an individual problem that can be solved with some effort by individuals, rather than that poverty is a national, structural, and systemic problem. (p. 277)

Thus, in the context of neoliberal Capitalism, divorcing poverty and homelessness from personal choice and responsibility seems nearly impossible.

There are also cultural assumptions about the ubiquity of comfortable middleclass homes, which show up in texts in many ways. As Grace Enriquez (2014) points out, "the constructed nature of texts [is] informed largely by the author's and illustrator's assumptions and outlook on the topic, as well as the reader's sociocultural interpretation" (p. 29). A striking example is the 2007 American Library Associations' May Hill Arbuthnot Honor Lecture by award-winning children's book author and illustrator Kevin Henkes, who uses home as the framework for his speech. He notes the worry he and his wife felt for their preschool aged son when the family moved from one house to another just a few blocks away: "he was sensitive and did not like change" (Henkes, 2017, p. 17). While sharing the angst his son experienced during this move, Henkes does not acknowledge that for many children, the difficult transition of moving is not one where they get to take their own bed and toys into a new room they have had the privilege to plan and decorate with their parents ahead of a carefully planned move. Further, Henkes makes what he clearly sees as an unequivocal statement: "A hallway is not a kitchen, nor a bedroom" (p. 19). However, for many people, including children living doubled-up with friends or family, or in temporary shelters, these middle-class distinctions are not a universal truth. Perhaps most troubling of all is that Henkes (like so many of us with positive experiences) equates home, in this case a single-family house, with safety and permanence without ever questioning what the inverse of that might mean, especially for children.

According to Bettina Kümmerling-Meibauer (2019) "little is known about when exactly children acquire and understand the concept of 'home' and whether picturebooks might enhance this process" (p. 121). Within early childhood education, the concepts of house and home are considered benign and age-appropriate themes for exploration in lessons with young children (Soundy, et al., 2007). Further, the books children read or have read to them in care settings, schools, and libraries represent narratives approved and perpetuated by the dominant culture. Smiljana NarančićKovač (2019) argues that "children's fiction influences the lives of children to help them understand the world and behave in the society according to adopted values and conventions" (p. 50). Thus, the images and words children see and read in books let them know in both subtle and blatant ways what is valued by their culture, what is normal and worthy of being included in a book. But as Stephanie Jones (2008) argues, the homes and family experiences young children see in books may not be representative of their lived experiences: "What kinds of economic lives are 
presented as normal and therefore desirable in children's picture books? Where are the picture books filled with trailer park homes? Barrio lives? Communal living? Joblessness? Homelessness? Simple living? Blue- and pink-collar employment? Government assistance?" (p. 43). More recently, the film adaptation of J.D. Vance's memoir, Hillbilly Elegy raised similar questions about how the disconnect between the creators of media and the lived experiences of people from rural, working-class, and/or lower-income backgrounds leads to those lives being distorted or misunderstood on the rare occasions they are made visible (Pruitt, 2020).

Home as a benign thematic topic for young children surfaces in picture books that explore home as a broad concept, not surprisingly in ways that privilege certain experiences of home over others. Aggregated representations of home were present in a number of books in the sample of this study, including in Mama Built a Little Nest (2014) by Jennifer Ward and Steve Jenkins, and Carson Ellis's Home (2015). Accompanying a two-page illustration of a bird in a nest looking into a child's private bedroom, Ward writes "You have a nest-your very own!/A place to rest you head/with pillows soft and cozy thoughts-." The assumption here is that any (every) child being read this book with have their own room and bed; this is expected, normal, and unassailable. Ellis describes and illustrates an array of homes, mostly single-family houses, although she does include an apartment, a band's tour bus (a nod to her involvement with the band, "The Decemberists"), a raccoon's burrow, and even a shoe. The implication is that whatever it looks like, everyone has a home, which may support the idea discussed above that children experience anywhere they live as home, or more likely, indicates a lack of understanding and awareness that in fact, not everyone does have a home.

\section{A Room of One's Own}

In her overview of a recent European project that explored the evolution of depictions of home in picture books after World War II, Carla Callegari (2019) explains that "The picturebooks... also give an account of how domestic spaces contribute to forming children's sense of identity, and their family and social relations" (p. 205). One finding noticed across the individual national studies in the project:

The bedroom and playroom are the children's private spaces. The bedroom, in particular, was interpreted by all six researchers involved in our project as having symbolic meaning. It represents the children's belonging to the home. The bed in their room is one of the items of furniture that appears in every country's picturebooks (Callegari, 2019, p. 226).

Large, private bedrooms are common in American picture books, represented in nearly a third (or 44 titles) of the books that feature any type of home, often depicted across a two-page spread. For example, in The House in the Night (2008) by Susan Marie Swanson and Beth Krommes, the child's bedroom is illustrated across a double spread, with a bed, a bookcase, dresser, an armchair and a rocking chair in the room. A violin is on the bed and a music stand is nearby. Similarly, in Bob Graham's "Let's get a pup," said Kate (2001), a scene of young Kate asleep on her bed with 
her dogs covers two pages. The bedroom features a wardrobe, dresser, bookcase and play table, with an abundance of toys, books, and clothes. There is a window that opens to a moonlit, fenced yard. Even when it is unclear if the characters live in a single-family home or another type of dwelling, the illustrations of the interior rooms are quite spacious and include many class-signifying features. In Lena's Shoes Are Nervous: A First-Day-of-School Dilemma (2018) by Keith Calabrese and Juana Medina, Lena's bedroom is shown across two pages and includes her bed, a large bookcase, long dresser, a beanbag chair, and a large window with a telescope pointing through it. The illustrations of the interior of where Penelope, a young dinosaur, and her family live in Ryan T. Higgins' We Don't Eat Our Classmates (2018) follow the same pattern. Penelope's bedroom is illustrated across two pages and features a bed, large bookcase, play table, and assorted toys. Even in the modest 1950s coastal home in Town is by the Sea (2017) by Joanne Schwartz and Sydney Smith, the interior spaces are surprisingly large. The bedroom of the boy narrator fills the double page layout, with a broad span of open floor between the dresser and bed, and a window so wide it looks to be twice the child's height. There are exceptions, and interestingly, in both Charlie \& Mouse (2017) and First Day in Grapes (2002), siblings not only seem to be sharing a bedroom, but also appear to be sharing the same bed.

As noted in the discussion of space, many of the interiors are illustrated with plentiful possessions, most notably a variety of toys and books in the children's bedrooms. The toys are charmingly old fashioned: teddy bears and other stuffed animals; balls; toy cars, planes and boats. As Sano (2009) notes, looking at visual and textual representations of children's material possessions in books can be a means for identifying characters' cultural capital. Consumption and other indicators of cultural capital are also indicative of social class (Aydin, 2006), thus, looking at material possessions and consumption are ways to determine social class status. Both the spaces and the belongings that fill them in the picture books in this study reinforce middle-class normalizing ideas of home as well as of childhood. The material possessions emphasize the family's valuing of play, creativity, and education, as suitable for the young characters. Books are plentiful, with bookcases standard features in most of the bedrooms. This alone may be an indication of the presumed socioeconomic class of the characters, as the number of books in the home has been correlated with income (Neuman and Celano, 2001) and the prevalence of "book deserts" in lower-income communities (Neuman and Moland, 2019).

\section{Kitchens Are the Heart of the Home}

The other interior home space that is often fraught with emotion and symbolism is the kitchen. In her study of Italian picture books, Marnie Campagnaro (2019) describes how the illustrations of full refrigerators and tables covered with food have an affective role, representing love and nurturance at a time when domestic spaces and family dynamics changed dramatically. Thirty-nine of the books in this study include illustrations of kitchen spaces or families eating meals together; in some, the visual clues do not provide enough information to determine if the family 
is eating in the kitchen or at a table in a dining room. Like the protagonists' bedrooms, kitchen spaces and family tables are often drawn across double-page spreads. For example, in Lena's Shoes Are Nervous: A First-Day-of-School Dilemma (2018) the family kitchen is shown across two pages and includes vast counter space, open shelving, and a kitchen island with stools. The kitchen in We Don't Eat Our Classmates (2018) is also large, with a table and chairs and a door to the outside.

Interestingly, while the books in the Italian study used abundant food to denote familial affection, in the U.S. books the same is achieved through images of shared meals. Human characters are shown in double-page spreads of dining tables in Momma, Where Are You From? (2000) by Marie Bradby and Chris Soentpiet, Marisol McDonald Doesn't Match (2011) by Monica Brown and Sara Palacios, and Not Afraid of Dogs (2006) by Susanna Pitzer and Larry Day. Even a bear family enjoys a shared meal at a large table across a two-page spread in Baby Bear's Chairs (2005) by Jane Yolen and Melissa Sweet. These illustrations show only modest amounts of food, including what is on individual family members' plates, and occasionally, pots or bowls being used for preparation. Thus, in the aggregate, these kitchen scenes reinforce middle-class values and norms around the nuclear family, the kitchen as shared and communal space, and even about appropriate food consumption.

\section{Apartments and Trailers}

Only eight percent of the books in this research sample included home settings that were clearly something other than single-family homes, in this case apartments or trailers. This is a rather small number considering that more than a third of U.S. households reside in settings other than single-family homes. How apartments are illustrated in this sample is also troubling. In both Jonathan Bean's At Night (2007) and John Rocco's Blackout (2011), the families live in what seem to be apartments - spaces within multistory buildings in urban settings, with architectural features connoting multifamily dwellings (flat roof, brick or stone exterior). Yet in both cases, the interior spaces more closely resemble single-family houses. In Blackout, the illustrations of the exterior of the building where the family live show that they occupy two floors of the building, with each of the four family members shown in a window, two upstairs, two downstairs. The young boy who wants to spend time with his family is shown taking a board game and walking down a flight of stairs to where his father is cooking and his mother is on the computer. In At Night, we see a staircase banister inside the family's dwelling, and the main character takes her bedding upstairs to the building roof which is furnished with plants, chairs, and a table. Thus, the access to and use of this outdoor space as a personal or private space aligns more closely with the spatial norms of single-family homes.

Perhaps the most realistic depiction of apartment dwelling in the sample is Meg Medina's Tía Isa Wants a Car (2011), illustrated by Claudio Muñoz. The young narrator and her aunt and uncle live in a multi-story apartment building. We see the narrator and Tía Isa outside the building, climbing the interior steps to their apartment, in the bedroom they share, and see Tío Andrés admiring their new car from their balcony. While the interior rooms are illustrated with décor items like area rugs, 
pictures on the walls, drapes and knick-knacks, the rooms are realistically sized for an apartment. The family's kitchen, for example, is illustrated with just enough room for the characters to barely move between the table and counters. In contrast to so many of the other books in the sample, the illustrations of the interior spaces in the apartment are drawn on single pages.

In two of the books in the sample, the families live in a trailer. The family in $I$ Know Here (2010) by Laurel Croza and Matt James lives in a community of trailers in Saskatchewan, Canada, while the narrator's father is working on a dam construction project. When the project is complete, the family will move to Toronto. There are no illustrations of the trailer's interior, but there is a double page spread showing the different types of trailers the workers live in, with a comparatively larger illustration of a fox in the foreground because someone is keeping a fox in a cage behind one of the trailers. In a strange coincidence, Rosemary Wells' Stella's Starliner (2014) is the story of a young fox who lives with her parents in a silver trailer. The illustrations show the trailer's sleeping area, living room, and kitchen space, as well as the family enjoying meals together. Stella loves her home until several weasels tease her about it. After sharing what was said and her hurt feelings with her mother, her parents respond by hitching the trailer to her father's truck and "flying...far away through the night." In their new location, Stella meets two young rabbits who think the Starliner is amazing and tell Stella that she "must be a millionaire to live in a silver house." There are deeply troubling messages about housing and shame at play in Stella's Starliner (2014) and that Wells opts to relocate the family rather than have Stella or her parents confront the weasels about their teasing is especially concerning. The implication is that living in a trailer is something shameful and that only when validated by others as seeming like something wealthy people do, is it not.

\section{Family Homelessness in Picture Books}

Because much of the impetus for this research project was my own work doing library story times with children in transitional housing shelters, I also examined the very few books for children that are about family homelessness. In their study of homelessness in American picture books, Kim and Wee (2020) reviewed 25 books published between 1990 and 2016 that deal with homelessness, were written for preschool to early elementary audiences, and were still in print. They found that "the representations of homelessness in children's picture books were described largely in stereotypical ways [and] retained negative and outdated portrayals of homelessness" (p. 368). Specifically, characters experiencing homelessness are depicted overwhelmingly as adults living in public spaces, and their appearance and behaviors are often described using negative and stereotypical language. Kelley and Darragh (2011) reviewed 58 picture books published after 1990 that have poverty as a central theme and a (presumed) setting in the U.S. A few of the books in their sample depicted homelessness explicitly, and the authors note that "Although these stories depict sad situations, they do represent reality for many homeless children in American schools today" (Kelley and Darragh, 2011, p. 273). There were only three 
picture books about families experiencing homelessness that were widely available at the time of the study. ${ }^{4}$

In A Shelter in Our Car (2004) written by Monica Gunning and illustrated by Elaine Pedlar, Zettie and her mother live in their car while her mother attends school and looks for work. Zettie is also in school and the family uses the facilities at the local park and shares their food with other people experiencing homelessness there. Pedlar's illustrations of the family readying for bed inside the car are done across the double-spread and stand in strong contrast to the spacious and possession-filled private bedrooms in books throughout the sample. At the end of the story, Zettie's mother has found a job and the family moves into a hotel, also shown across two pages. In Still a Family (2017) by Brenda Reeves Sturgis and Jo-Shin Lee, the nameless narrator and her mother stay in a women's shelter, while her father has to stay at a nearby men's shelter. ${ }^{5}$ The illustrations are meant to mimic a child's crayon drawings and show the dormitory sleeping arrangements of the women and children's shelter where the child and her mother stay, as well as the family eating together at a soup kitchen. The final book, A Place to Stay: A Shelter Story (2019) written by Erin Gunti and illustrated by Estelí Meza, includes many of the same interior features of homes in the broader sample within a family shelter. In this book, a young girl (also nameless) and her mother arrive at the shelter and use their imaginations to transform the experience into something wondrous. Yet the interior spaces are drawn as very welcoming and homey even without having to reimagine them. There are shared living spaces for watching television, as well as a room filled with books and toys. The common eating area features a cafeteria-style line and tables. The room the child and her mother share is illustrated across two pages; with two beds, artwork on the wall and a shared nightstand, it resembles a hotel room. Each of these three books includes notes for readers about homelessness, all with a call for action and activism to address homelessness. As Kelley and Darragh (2011) found in their study, these books put the emphasis on charitable and personal action rather than on systemic change to address housing depravation.

\section{Conclusion}

Social class and economic privilege remain elephants in the room of children's literature. While completing this project in the midst of the COVID-19 pandemic, the challenges children in low-income and homeless situations face in terms of education and access became ever more apparent, as did our collective assumptions about class and privilege. While it goes without saying that housing insecurity and homelessness are urgent social issues, they are also the lived experiences of millions of

\footnotetext{
${ }^{4}$ Susin Nielsen-Furland's The Magic Beads (2007) is out of print in hardcover and unavailable; it is being rereleased in paperback in August 2021.

5 This is a common practice in many shelters. Often even older male children are excluded from staying in family shelters. Families thus face difficult decisions about splitting up and may refuse shelter to avoid those separations.
} 
American children and despite the traumas and challenges associated with unstable housing, children in these circumstances still experience childhood with all of its joys and heartache unrelated to housing. What might it look like if books for young children simply featured home settings that were not large, well-provisioned spaces, but rather cramped apartment, trailers, or shelters, without making these living situations the center of the plot and thereby implying they are inherently problematic? There may be a fear that including these types of housing in books for young people sends a message that childhood homelessness is acceptable, that their inclusion in media would normalize these settings and situations. I argue that the array of housing lived in by young children and their families, including those substandard conditions and temporary shelters that constitute homelessness, have already been normalized by neoliberal capitalism, while also being shrouded in shame and stigma directed at families rather than at the systems that force so many into untenable situations. The array of experiences children bring with them to classrooms, libraries, and all of their interactions with books and literature must be acknowledged and validated by educators and ultimately by authors, illustrators, and publishers. The continued absence of diverse socioeconomic class experiences in picture books, or the relegation of the experiences of people from lower-income or working-class backgrounds to "problem" and "issue" books is unconscionable and needs to be recognized and addressed so that all children may see reflections of themselves, their families, and their lives in the books we offer them to read. Thus, the goal of this research is not to advocate for more and better quality "homelessness" books for children (although they are certainly needed), but rather to argue for the inclusion of an array of housing settings in books where home is merely background rather than integral to the plot.

Acknowledgments I gratefully acknowledge the generous financial support for the initial research for this project provided by the Kent State University School of Library and Information Science's Jacqueline M. Albers Guest Scholar in Children's Literature Fellowship and conducted in the Marantz Picturebook Collection for the Study of Picturebook Art in the Reinberger Children's Library Center.

\section{References}

America's Youngest Outcasts: A Report Card on Child Homelessness. (2014). Waltham. MA: The National Center on Family Homelessness at American Institutes for Research.

Aydin, Kemal. (2006). Social Stratification and Consumption Patterns in Turkey. Social Indicators Research, 75(3), 463-501.

Bean, Jonathan. (2007). At Night. New York: Farrar, Straus and Giroux (BYR).

Bishop, Rudine Sims. (1990). Mirrors, Windows, and Sliding Glass Doors. Perspectives, 6(3), ix-xi. Bradby, Marie, and Soentpiet, Chris. (2000). Momma, Where Are You From?. London: Orchard Books.

Brown, Monica, and Palacios, Sara. (2011). Marisol McDonald Doesn't Match. New York: Children's Book Press.

Calabrese, Keith, and Medina, Juana. (2018). Lena's Shoes Are Nervous: A First-Day-of-School Dilemma. New York: Atheneum Books for Young Readers.

Callegari, Carla. (2019). Reasons for the Research on the Construction of the Sense of espace vecu in European Children's Literature in the Second Half of the 20th Century (1945-2010). An 
International Historical and Comparative Survey on Picturebooks: Goals, Method, Tools, and Preliminary Results. Ricerche di Pedagogia e Didattica, 14(2), 203-236.

Campagnaro, Marnie. (2019). "Narrating" Homes and Objects: Images of Domestic life in Italian Picturebooks Since the Mid-20th Century. Ricerche di Pedagogia e Didattica. Journal of Theories and Research in Education, 14(2), 9-48.

Child Trends. (2019). Children and Youth Experiencing Homelessness. www.childtrends.org/indicators/ homeless-children-and-youth.

Croza, Laurel, and James, Matt. (2010). I Know Here. Toronto: Groundwood Books/House of Anansi Press.

da Costa Nunez, Ralph. (2010). A Shelter Is Not a Home- or Is It?: Revisited. White Tiger Press.

de Bradley, Ann Aviles. (2015). From Charity to Equity Race, Homelessness, and Urban Schools. New York: Teachers College Press.

Desmond, Matthew. (2016). Evicted: Poverty and Profit in the American City. New York: Crown.

Ellis, Carson. (2015). Home. Somerville, MA: Candlewick Press.

Enriquez, G. (2014). Critiquing Social Justice Picturebooks: Teachers' Critical Literacy Reader Responses. New England Reading Association Journal, 50(1), 27-37, 83.

Frederick, Tyler J., et al. (2014). How Stable is Stable? Defining and Measuring Housing Stability. Journal of Community Psychology, 42(8), 964-979.

Graham, Bob. (2001). Let's Get a Pup, Said Kate. Somerville, MA: Candlewick Press.

Gunning, Monica, and Pedlar, Elaine. (2004). A Shelter in Our Car. New York: Children's Book Press.

Gunti, Erin, and Meza, Estelí. (2019). A Place to Stay: A Shelter Story. Cambridge, MA: Barefoot Books.

Henkes, Kevin. (2017). Books as Shelter: Going Home Again and Again. May Hill Arbuthenot Lecture. https://alair.ala.org/handle/11213/6271.

Higgins, Ryan T. (2018). We Don't Eat Our Classmates. Los Angeles: Disney/Hyperion Books.

Jones, Stephanie. (2008). Grass Houses: Representations and Reinventions of Social Class Through Children's Literature. Journal of Language and Literacy Education, 4(2), 40-58.

Kelley, Jane E., and Darragh, Janine J. (2011). Depictions and Gaps: Portrayal of US Poverty in Realistic Fiction Children's Picture Books. Reading Horizons: A Journal of Literacy and Language Arts, 50(4), 263-282.

Kim, Jinhee, and Wee, Su-Jeong. (2020). Silent Voices of Homelessness: Content Analysis of Homelessness in Children's Picture Books Published in the US from 1990 to 2016. Early Child Development and Care, 190(3), 364-375.

Kümmerling-Meibauer, Bettina. (2019). Is There Really No Place Like Home? Changes in the Perception of Domestic Spaces in German Picturebooks from 1945 to the Present. Ricerche di Pedagogia e Didattica. Journal of Theories and Research in Education, 14(2), 117-143.

Kushel, Margot B., et al. (2006). Housing Instability and Food Insecurity as Barriers to Health Care Among Low-Income Americans. Journal of General Internal Medicine, 21(1), 71-77.

Maslow, Abraham H. (1954). Motivation and Personality. New York: Harpers.

Medina, Meg, and Munoz, Claudio. (2011). Tì Isa Wants a Car. Somerville, MA: Candlewick Press.

Narančić-Kovač, Smiljana. (2019). Lived Spaces in Croatian Picturebooks: Public and Private Places and the Sense of Belonging. Ricerche di Pedagogia e Didattica. Journal of Theories and Research in Education, 14(2), 49-85.

NCCP. (n.d.) Child Poverty. National Center for Children in Poverty. www.ncep.org/topics/childpoverty. html.

Neuman, Susan B., and Celano, Donna. (2001). Access to Print in Low-Income and Middle-Income Communities: An Ecological Study of Four Neighborhoods. Reading Research Quarterly, 36(1), $8-26$.

Neuman, Susan B., and Moland, Naomi. (2019). Book Deserts: The Consequences of Income Segregation on Children's Access to Print. Urban Education, 54(1), 126-147.

Nodelman, Perry, and Reimer, Mavis. (2003). The Pleasures of Children's Literature. Boston: Allyn and Bacon.

Pascale, Celine-Marie. (2005). There's No Place Like Home: The Discursive Creation of Homelessness. Cultural Studies? Critical Methodologies, 5(2), 250-268.

Perez, L.King, and Casilla, Robert. (2002). First Day in Grapes. New York: Lee \& Low Books.

Pitzer, Susanna, and Day, Larry. (2006). Not Afraid of Dogs. London: Walker Children's.

Pruitt, L. R. (2020). The chattering classes Got the "Hillbilly Elegy" Book Wrong - and They're Getting the Movie Wrong, Too. The Conversation. http://theconversation.com/the-chattering-classes-got-thehillbilly-elegy-book-wrong-and-theyre-getting-the-movie-wrong-too-150937. 
Rocco, John. (2011). Blackout. Los Angeles: Disney/Hyperion Books.

Sano, Joelle. (2009). Farmhands and Factory Workers, Honesty and Humility: The Portrayal of Social Class and Morals in English Language Learner Children's Books. Teachers College Record, 111(11), 2560-2588.

Schwartz, Joanne, and Smith, Sydney. (2017). Town is by the Sea. Toronto: Groundwood Books.

Sipe, Lawrence R. (2011). The Art of the Picturebook. In Shelby Wolf, Karen Coats, and Patricia Enciso (Eds.), Handbook of Research on Children's and Young Adult Literature (pp. 238-252). Routledge.

Snyder, Laurel, and Hughes, Emily. (2017). Charlie \& Mouse. San Francisco: Chronicle Books.

Soundy, Cathleen S., Guha, Smita, and Qiu, Yun. (2007). Picture Power: Placing Artistry and Literacy on the Same Page. YC Young Children, 62(3), 82.

Sturgis, Brenda Reeves, and Lee, Jo-Shin. (2017). Still a Family. Chicago: Albert Whitman \& Company.

Swanson, Susan Marie, and Krommes, Beth. (2008). The House in the Night. Boston: Houghton Mifflin Company.

United States Census Bureau. (2018). Selected housing characteristics American Community Survey. www.data.census.gov/cedsci/table $\mathrm{q}=$ housing\&hidePreview $=$ false \&tid=ACSDP1Y2018.DP04\&t= Housing.

[USC02] 42 USC CHAPTER 119, SUBCHAPTER VI, Part B: Education for Homeless Children and Youths. www.uscode.house.gov/view.xhtml?path=/prelim@title42/chapter119/subchapter6/partB\& edition=prelim.

Ward, Jennifer, and Jenkins, Steve. (2014). Mama Built a Little Nest. San Diego: Beach Lane Books.

Wells, Rosemary. (2014). Stella's Starliner. Somerville, MA: Candlewick Press.

Yolen, Jane and Sweet, Melissa. (2005). Baby Bear's Chairs. San Diego: Harcourt Children's Books.

\section{Appendix: Booklist}

Agee, Jon. (2015). It's Only Stanley. New York: Dial Books for Young Readers.

Alexie, Sherman and Morales, Yuri. (2016). Thunder Boy Jr. New York: Little, Brown and Company.

Aponte, Carlos and Aponte, Carlos. (2019). Across the Bay. New York: Penguin Workshop.

Appelt, Kathi and Mcelmurry, Jill. (2015). When Otis Courted Mama. Boston: Houghton Mifflin Harcourt.

Archer, Micha and Archer, Micha. (2016). Daniel Finds a Poem. New York: Nancy Paulsen Books.

Argueta, Jorge (Elisa Amado, trans) and Tonatiuh, Duncan. (2015). Salsa: Un Poema Para Cocinar/A Cooking Poem. Toronto: Groundwood Books/House of Anansi Press.

Ashman, Linda and Stringer, Lauren. (2001). Castles, Caves and Honeycombs. San Diego: Harcourt Children's Books.

Bachelet, Gilles. (2006). My Cat, the Silliest Cat in the World. New York: Abrams Books for Young Readers.

Balouch, Kristen. (2006). Mystery Bottle. Los Angeles: Hyperion.

Bang, Molly. (1999). When Sophie Gets Angry-Really, Really Angry. New York: Blue Sky Press.

Bania, Michael. (2004). Kumak's Fish: A Tall Tale from the Far North. Anchorage: Alaska Northwest Books.

Barnett, Mac and Cornell, Kevin. (2013). Count the Monkeys. Los Angeles: Disney/Hyperion.

Barnett, Mac and Klassen, Jon. (2012). Extra Yarn. New York: Balzer \& Bray.

Barnett, Mac and Klassen, Jon. (2014). Sam \& Dave Dig a Hole. Somerville, MA: Candlewick Press.

Barnett, Mac and Robinson, Christian. (2015). Leo: A Ghost Story. San Francisco: Chronicle Books.

Bean, Jonathan. (2007). At Night. New York: Farrar, Straus and Giroux (BYR).

Bean, Jonathan. (2013). Building our House. New York: Farrar, Straus and Giroux.

Beaumont, Karen and Catrow, David. (2004). I Like Myself. Boston: Houghton Mifflin Harcourt.

Becker, Aaron. (2013). Journey. Somerville, MA: Candlewick Press.

Becker, Bonny and Denton, Kady MacDonald. (2008). A Visitor for Bear. Cambridge, MA: Candlewick Press.

Bell, Cece. (2015). I Yam a Donkey! Boston: Clarion Books.

Biedrzycki, David. (2011). Me and My Dragon. Watertown, MA: Charlesbridge.

Bildner, Phil and Parra, John. (2015). Marvelous Cornelius. San Francisco: Chronicle Books.

Bingham, Kelly and Zelinsky, Paul O. (2012). Z is for Moose. New York: Greenwillow Books. 
Birtha, Becky and Bootman, Colin. (2005). Grandmama's Pride. Park Ridge, IL: Albert Whitman \& Company.

Bluemle, Elizabeth and Cecil, Randy. (2006). My Father the Dog. Cambridge, MA: Candlewick Press.

Bluemle, Elizabeth and Karas, G. Brian. (2014). Tap Tap Boom Boom.Somerville, MA: Candlewick Press.

Bradby, Marie and Soentpiet, Chris. (2000). Momma, Where Are You From? London: Orchard.

Brown, Monica and Colon, Raul. (2007). My Name Is Gabito: The Life of Gabriel Garcia Marquez. Flagstaff, AZ: Rising Moon.

Brown, Monica and Lopez, Rafael. (2013). Tito Puente: Mambo King/Rey del Mambo. New York: HarperCollins Publishers.

Brown, Monica and Palacios, Sara. (2011). Marisol McDonald Doesn't Match. San Francisco: Children's Book Press.

Brown, Monica and Parra, John. (2017). Frida Kahlo and Her Animalitos. New York: NorthSouth Books. Brown, Peter. (2013). Mr. Tiger Goes Wild. New York: Little, Brown and Company.

Brown, Peter. (2014). My Teacher is a Monster! (No, I am Not). New York: Little, Brown and Company.

Bryant, Jen and Sweet, Melissa. (2008). A River of Words: The Story of William Carlos Williams. Grand Rapids, MI: Eerdmans Books for Young Readers.

Bryant, Jen and Sweet, Melissa. (2014). The Right Word: Roget and his Thesaurus. Grand Rapids, MI: Eerdmans Books for Young Readers.

Bunting, Eve and Castillo, Lauren. (2015). Yard Sale. Somerville, MA: Candlewick Press.

Buzzeo, Tony and Small, David. (2012). One Cool Friend. New York: Dial Books for Young Readers.

Calabrese, Keith and Medina, Juana. (2018). Lena's Shoes Are Nervous: A First-Day-of-School Dilemma. New York: Atheneum Books for Young Readers.

Camcam, Princesse. (2014). Fox's Garden. Brooklyn, NY: Enchanted Lion Books.

Campbell, K. G. (2012). Lester's Dreadful Sweaters. Toronto: Kids Can Press.

Castillo, Lauren. (2014). Nana in the City. Boston: Clarion Books.

Chodos-Irvine, Margaret. (2003). Ella Sarah Gets Dressed. San Diego: Harcourt.

Cole, Heidi and Vogl, Nancy and Purnell, Gerald. (2005). Am I a Color Too?. Bellevue, WA: Illumination Arts Publishing Company.

Collier, Bryan. (2004). Uptown. New York: Henry Holt.

Cooper, Elisha. (2017). Big Cat, Little Cat. New York: Roaring Brook Press.

Crimi, Carolyn and Molk, Laurel. (2017). There Might Be Lobsters. Somerville, MA: Candlewick Press.

Cronin, Doreen and Lewin, Betsy. (2000). Click, Clack, Moo: Cows that Type. New York: Simon \& Schuster Books for Young Readers.

Croza, Laurel and James, Matt. (2013). I Know Here. Toronto: Groundwood Books/House of Anansi Press.

Cunnane, Kelly and Hadahi, Hoda. (2013). Deep in the Sahara. New York: Schwartz \& Wade Books.

Cunnane, Kelly and Juan, Ana. (2006). For You Are a Kenyan Child. New York: Atheneum Books for Young Readers.

Cutbill, Andy and Ayto, Russell. (2008). The Cow that Laid an Egg. New York: HarperCollins.

Davies, Matt. (2015). Ben Draws Trouble. New York: Roaring Brook Press.

DeFelice, Cynthia C. and Parker, Robert Andrew. (2000). Cold Feet. New York: DK Publishing.

DeFelice, Cynthia C. and U'Ren, Andrea. (2006). One Potato, Two Potato. New York: Farrar Straus Giroux.

Denos, Julia and Goodale, E. B. (2017). Windows. Somerville, MA: Candlewick Press.

Dewdney, Anna. (2005). Llama Llama Red Pajama. New York: Viking.

Diaz, Junot and Espinosa, Leo. (2018). Islandborn. New York: Dial Books for Young Readers.

DiPucchio, Kelly and Robinson, Christian. (2014). Gaston. New York: Atheneum Books for Young Readers.

Dorros, Arthur and Gutierrez, Rudy. (2008). Papa and Me. New York: HarperCollins Publishers.

Dotlich, Rebecca Kai and Leijten, Aileen. (2009). Bella \& Bean. New York: Atheneum Books for Young Readers.

Drew, Daywalt and Jeffers, Oliver. (2013). The Day the Crayons Quit. New York: Philomel Books.

Durango, Julia and Diaz, Bianca. (2017). The One Day House. Watertown, MA: Charlesbridge.

Dyckman, Ame and Campbell, K. G. (2013). Tea Party Rules. New York: Viking.

Dyckman, Ame and O'Hora, Zachariah. (2015). Wolfie, the Bunny. New York: Little, Brown and Company.

Ehlert, Lois. (2005). Leaf Man. Orlando: Harcourt. 
Ellis, Carson. (2015). Home. Somerville, MA: Candlewick Press.

Engle, Margarita and Lopez, Rafael. (2015). Drum Dream Girl. Boston: Houghton Mifflin Harcourt.

Eversole, Robyn and Coffey, Tim. (1999). Red Berry Wool. Park Ridge, IL: Albert Whitman \& Company. Falconer, Ian. (2000). Olivia. New York: Atheneum Books for Young Readers.

Fleming, Candace and Rohmann, Eric. (2012). Oh, No! New York: Schwartz \& Wade Books.

Fletcher, Ralph and Cowdrey, Richard. (2008). The Sandman. New York: Henry Holt and Company.

Floca, Brian. (2013). Locomotive. New York: Atheneum Books for Young Readers.

Frame, Jeron Ashford and Christie, R. Gregory. (2003). Yesterday I Had the Blues. Berkeley, CA: Tricyle Press.

Frazee, Marla. (2008). A Couple of Boys Have the Best Week Ever. Orlando: Harcourt.

Frazier, Craig. (2005). Stanley Mows the Lawn. San Francisco: Chronicle Books.

Fromental, Jean-Luc and Jolivet, Joelle. (2017). 365 Penguins. New York: Abrams Books for Young Readers.

Gerstein, Mordicai. (2003). The Man Who Walked Between the Towers. Brookfield, CT: Roaring Brook Press.

Giovanni, Nikki and Collier, Bryan. (2005). Rosa. New York: Henry Holt.

Gonzalez, Maya Christina. (2007). My Colors, My World=Mis Colores, Mi Mundo. San Francisco: Children's Book Press.

Gonzalez, Raul. (2019). Vamos! Let's Go to the Market. Boston: Versify, Houghton Mifflin Harcourt.

Gonzalez, Xelena and Garcia, Adriana M. (2017). All Around Us. El Paso, TX: Cinco Puntos Press.

Graham, Bob. (2001). “Let's get a pup,” said Kate. Cambridge, MA: Candlewick Press.

Graham, Bob. (2017). Home in the Rain. Somerville, MA: Candlewick Press.

Grey, Mini. (2012). Traction Man is Here! New York: Knopf.

Hatanaka, Kellen. (2014). Work, an Occupational ABC. Toronto: Groundwood Books.

Henkes, Kevin. (2004). Kitten's First Full Moon. New York: Greenwillow Books.

Higgins, Ryan. (2013). Wilfred. London: Dial Books.

Higgins, Ryan T. (2018). We Don't Eat Our Classmates: Los Angeles: Disney/Hyperion.

Hill, Laban Carrick, and Collier, Bryan. (2010). Dave the Potter: Artist. Slave: Poet.

Howard, Elizabeth Fitzgerald and Lewis, E. B. (2000). Virgie Goes to School with Us Boys. New York: Simon \& Schuster Books for Young Readers.

Howitt, Mary and DiTerlizzi, Tony. (2002). The Spider and the Fly. New York: Simon \& Schuster Books for Young Readers.

Idle, Molly. (2013). Flora and the Flamingo. San Francisco: Chronicle Books.

Isadora, Rachel. (2013). Old Mikamba Had a Farm. New York: Nancy Paulsen Books.

Jenkins, Steve and Page, Robin. (2003). What Do You Do with a Tail Like This? Boston: Houghton Mifflin.

Johnson, Angela and Long, Loren. (2003). I Dream of Trains. New York: Simon \& Schuster Books for Young Readers.

Johnson, D. B. (2000). Henry Hikes to Fitchburg. Boston: Houghton Mifflin.

Johnston, Tony and Morales, Yuyi. (2009). My Abuelita. Orlando: Harcourt.

Juan, Ana. (2004). The Night Eater. New York: Arthur A. Levine Books.

Juanita, Kaylani and Lukoff, Kyle. (2019). When Aidan Became a Brother. New York: Lee \& Low Books, Inc.

Juster, Norton and Raschka, Chris. (2005). The Hello, Goodbye Window. New York: Hyperion Books for Children.

Kerley, Barbara and Selznick, Brian. (2001). The Dinosaurs of Waterhouse Hawkins. New York: Scholastic.

Kettelman, Helen and Terry, Will. (2009). The Three Little Gators. Park Ridge, IL: Albert Whitman \& Company.

Khan, Rukhsana and Blackall, Sophie. (2010). Big Red Lollipop. New York: Viking.

Klassen, Jon. (2012). This is Not My Hat. Somerville, MA: Candlewick Press.

Kostecki-Shaw, Jenny Sue. (2011). Same, Same, But Different. New York: Henry Holt.

Krasnesky, Thad and Parkins, David. (2010). That Cat Can't Stay. Brooklyn, NY: Flashlight Press.

Laminack, Lester L. and Gustavson, Adam. (2007). Snow Day! Atlanta: Peachtree.

LaRochelle, David and Egielski, Richard. (2007). The End. New York: Arthur A. Levine Books.

LaRochelle, David and Fearing, Mark. (2013). How Martha Saved Her Parents from Green Beans. New York: Dial Books for Young Readers.

Lehman, Barbara. (2004). The Red Book. Boston: Houghton Mifflin. 
Levine, Ellen and Nelson, Kadir. (2007). Henry's Freedom Box: A True Story from the Underground Railroad. New York: Scholastic Press.

Lewis, J. Patrick and Sheban, Chris. (2001). The Shoe Tree of Chagrin. Mankato, MN: Creative Co.

Light, Steve. (2014). Have You Seen My Dragon? Somerville, MA: Candlewick Press.

Lin, Grace. (2018). A Big Mooncake for Little Star. New York: Little, Brown and Company.

Logue, Mary and Zagarenski, Pamela. (2012). Sleep Like a Tiger. Boston: Houghton Mifflin Books for Children.

Love, Jessica. (2018). Julian is a Mermaid. Somerville, MA: Candlewick Press.

Lyons, Kelly Starling and Minter, Daniel. (2019). Going Down Home with Daddy. Atlanta: Peachtree Publishers.

Mahy, Margaret and Dunbar, Polly. (2008). Bubble Trouble. New York: Clarion Books.

Mavor, Salley. (2010). A Pocketful of Posies. Boston: Houghton Mifflin Books for Children.

McCarty, Peter. (2002). Hondo \& Fabian. New York: Henry Holt.

McDonnell, Patrick. (2014). A Perfectly Messed-Up Story. New York: Little, Brown and Company.

McDonnell, Patrick. (2011). Me...Jane. New York: Little, Brown and Company.

McKissack, Patricia C. and Pinkney, Jerry. (2001). Goin' Someplace Special. New York: Atheneum Books for Young Readers.

McLimans, David. (2006). Gone Wild: An Endangered Animal Alphabet. New York: Walker.

Medina, Meg and Munoz, Claudio. (2011). Tía Isa Wants a Car. Somerville, MA: Candlewick Press.

Miller, Pat Zietlow and Wilsdorf, Anne. (2013). Sophie's Squash. New York: Schwartz \& Wade Books.

Mollel, Tololwa M. and Lewis, E. B. (1999). My Rows and Piles of Coins. New York: Clarion Books.

Montes, Marisa and Morales, Yuyi. (2006). Los Gatos Black on Halloween. New York: Henry Holt.

Mora, Oge. (2018). Thank You, Omu! Boston: Little, Brown and Company.

Mora, Pat, and So, Meilo. (2014). Water Rolls. Water Rises: El agua rueda, el agua sube.

Morales, Yuyi and O'Meara, Tim. (2014). Viva Frida. New York: Roaring Brook Press.

Morales, Yuyi. (2016). Little Night. New Milford, CT: Roaring Brook Press.

Moundlic, Charlotte and Tallec, Olivier. (2013). The Bathing Costume, or, the Worst Vacation of My Life. New York: Enchanted Lion Books.

Muth, Jon J. (2005). Zen Shorts. New York: Scholastic Press.

Nelson, Vaunda Micheaux and Bootman, Colin. (2003). Almost to Freedom. Minneapolis, MN: Carolrhoda Books.

Perez, L. King and Casilla, Robert. (2002). First Day in Grapes. New York: Lee \& Low Books.

Pinkney, Jerry. (2009). The Lion \& the Mouse. New York: Little, Brown Books for Young Readers.

Pinkney, Jerry. (2002). Noah's Ark. San Francisco: Chronicle Books.

Pinkney, Jerry (HC Andersen). (1999). The Ugly Duckling. New York: Morrow Junior Books.

Pitzer, Susanna and Day, Larry. (2006). Not Afraid of Dogs. London: Walker Childrens.

Portis, Antoinette. (2014). Froodle. New York: Roaring Brook Press.

Priceman, Marjorie. (2005). Hot Air: The (Mostly) True Story of the First Hot-Air Balloon Ride. New York: Atheneum Books for Young Readers.

Quintero, Isabel and Pena, Zeke. (2019). My Papi Has a Motorcycle. New York: Kokila.

Rappaport, Doreen, and Collier, Bryan. (2001). Martin's Big Words: The Life of Dr. Jr: Martin Luther King.

Raschka, Chris. (2011). A Ball for Daisy. New York: Schwartz \& Wade Books.

Redmond. E. S. (2009). Felicity Floo Visits the Zoo. Somerville, MA: Candlewick Press.

Rex, Adam and Timberlake, Amy. (2003). The Dirty Cowboy. New York: Farrar, Straus and Giroux.

Reynolds, Aaron and Brown, Peter. (2012). Creepy Carrots! New York: Simon \& Schuster Books for Young Readers.

Rocco, John. (2011). Blackout. New York: Disney/Hyperion Books.

Rockliff, Mara and Low, William. (2012). Me and Momma and Big John. Somerville, MA: Candlewick Press.

Rohmann, Eric. (2002). My Friend Rabbit. Brookfield, CT: Roaring Brook Press.

Root, Phyllis and Oxenbury, Helen. (2002). Big Momma Makes the World. Cambridge, MA: Candlewick Press.

Rosenstock, Barb and GrandPre, Mary. (2014). The Noisy Paint Box: The Colors and Sounds of Kandinsky's Abstract Art. New York: Alfred A. Knopf.

Rosenthal, Amy Krouse and Lichtenheld, Tom. (2013). Exclamation Mark. New York: Scholastic Press.

Rosenthal, Amy Krouse and Roberts, David. (2018). Don't Blink. New York: Random House Children's Books. 
Ruzzier, Sergio. (2018). The Party and Other Stories. San Francisco: Chronicle Books.

Santat, Dan. (2014). The Adventures of Beekle: The Unimaginary Friend. New York: Little, Brown and Company.

Sayre, April Pulley and Jenkins, Steve. (2013). Eat Like a Bear. New York: Henry Holt and Company.

Scanlon, Liz Garton and Frazee, Marla. (2009). All the World. New York: Beach Lane Books.

Schwartz, Joanne and Smith, Sydney. (2017). Town is By the Sea. Toronto: Groundwood Books/House of Anansi Press.

Scillian, Devnin and Bowers, Tim. (2010). Memoirs of a Goldfish. Ann Arbor, MI: Sleeping Bear Press.

Seeger, Laura Vaccaro. (2007). Dog and Bear: Two Friends, Three Stories. New Milford, CT: Roaring Brook Press.

Seeger, Laura Vaccaro. (2007). First the Egg. New Milford, CT: Roaring Brook Press.

Seeger, Laura Vaccaro. (2012). Green. New York: Roaring Brook Press.

Shannon, David. (2000). The Rain Came Down. New York: Blue Sky Press.

Shannon, George and Gomez, Blanca. (2015). One Family. New York: Farrar, Straus and Giroux.

Shetterly, Margot Lee and Freeman, Laura. (2018). Hidden Figures. New York: Harper.

Shulevitz, Uri. (2008). How I Learned Geography. New York: Farrar, Straus and Giroux.

Sidman, Joyce and Allen, Rick. (2014). Winter Bees \& Other Poems of the Cold. Boston: Houghton Mifflin Harcourt.

Sidman, Joyce and Prange, Beckie. (2005). Song of the Water Boatman and Other Pond Poems. Boston: Houghton Mifflin.

Sidman, Joyce and Zagarenski, Pamela. (2009). Red Sings from Treetops: A Year in Colors. Boston: Houghton Mifflin Books for Children.

Siegelson, Kim L. and Pinkney, Brian. (1999). In the Time of the Drums. New York: Hyperion Books.

Simont, Marc. (2001). The Stray Dog. New York: HarperCollins.

Sis, Peter. (2007). The Wall: Growing Up Behind the Iron Curtain. New York: Frances Foster Books.

Smallcomb, Pam and Berger, Joe. (2011). Earth to Clunk. London: Dial Books.

Smith, Lane. (2011). Grandpa Green. New York: Roaring Brook Press.

Snyder, Laurel and Hughes, Emily. (2017). Charlie \& Mouse. San Francisco: Chronicle Books.

Snyder, Laurel and Morstad, Julie. (2015). Swan: The Life and Dance of Anna Pavlova. San Francisco: Chronicle Books.

Spires, Ashley. (2014). The Most Magnificent Thing. Toronto: Kids Can Press.

St. George, Judith and Small, David. (2000). So You Want to Be President? New York: Philomel Books.

Stead, Philip C. and Stead, Erin. E. (2010). A Sick Day for Amos McGee. New York: Roaring Brook Press.

Stein, David Ezra. (2010). Interrupting Chicken. Somerville, MA: Candlewick Press.

Stevens, Janet and Crummel, Susan Stevens. (2005). The Great Fuzz. Frenzy. Boston: HMH Books for Young Readers.

Stower, Adam. (2012). Silly Doggy! London: Orchard Books.

Sturges, Philomen and Walrod, Amy. (1999). The Little Red Hen (Makes a Pizza). New York: Dutton Children's Books.

Swanson, Susan Marie and Krommes, Beth. (2008). The House in the Night. Boston: Houghton Mifflin Company.

Taback, Simms. (1999). Joseph Had a Little Overcoat. New York: Viking.

Tallec, Olivier. (2015). Who Done It? San Francisco: Chronicle Books.

Thayer, Ernest and Bing, Christopher. (2000). Casey at the Bat. Toronto: KCP Poetry/Kids Can Press.

Thompson, Lauren and Bean, Jonathan. (2007). The Apple Pie that Papa Baked. New York: Simon \& Schuster Books for Young Readers.

Tonatiuh, Duncan. (2010). Dear Primo: a Letter to My Cousin. New York: Abrams Books for Young Readers.

Tonatiuh, Duncan. (2011). Diego Rivera: His World and Ours. New York: Abrams Books for Young Readers.

Tusa, Tricia. (2011). Follow Me. Boston: HMH Books for Young Readers.

Uegaki, Chieri and Leng, Qin. (2014). Hana Hashimoto, Sixth Violin. Toronto: Kids Can Press.

Updike, John and Hyman, Tricia Schart. (1999). A Child's Calendar. New York: Holiday House.

Vischer, Frans. (2011). Fuddles. New York: Aladdin.

Ward, Jennifer and Jenkins, Steve. (2014). Mama Built a Little Nest. New York: Beach Lane Books.

Watkins, Rowboat. (2015). Rude Cakes. San Francisco: Chronicle Books. 
Weatherford, Carole Boston and Nelson, Kadir. (2006). Moses: When Harriet Tubman Led Her People to Freedom. New York: Jump at the Sun/Hyperion Books for Children.

Weatherford, Carole Boston and Qualls, Sean. (2008). Before John Was a Jazz Giant. New York: Henry Holt.

Wells, Rosemary. (2014). Stella's Starliner. Somerville, MA: Candlewick Press.

Wenzel, Brendan. (2016). They All Saw a Cat. San Francisco: Chronicle Books.

Wheeler, Lisa and Goembel, Ponder. (2002). Sailor Moo, Cow at Sea. New York: Atheneum/Richard Jackson Books.

Whelan, Gloria and Carpenter, Nancy. (2014). Queen Victoria's Bathing Machine. New York: Simon \& Schuster Books for Young Readers.

Whitman, Walt and Long, Loren. (2004). When I Heard the Learn'd Astronomer. New York: Simon \& Schuster Books for Young Readers.

Wiesner, David. (2006). Flotsam. New Yorl: Clarion Books.

Wiesner, David. (2013). Mr. Wuffles! New York: Clarion Books.

Wiesner, David. (1999). Sector 7. New York: Clarion Books.

Wiesner, David. (2001). The Three Pigs. New York: Clarion Books.

Willems, Mo. (2003). Don't Let the Pigeon Drive the Bus. New York: Hyperion Books for Children.

Willems, Mo. (2007). Knuffle Bunny Too: A Case of Mistaken Identity. New York: Hyperion Books for Children.

Willems, Mo. (2004). Knuffle Bunny: A Cautionary Tale. New York: Hyperion Books for Children.

Willems, Mo. (2014). The Pigeon Needs a Bath! New York: Hyperion Books for Children.

Wilson, Karma and Hall, Marcellus. (2010). The Cow Loves Cookies. New York: Margaret K. McElderry Books.

Wilson, Sarah and Cameron, Chad. (2004). George Hogglesberry, Grade School Alien. Berkeley, CA: Tricycle Press.

Woodson, Jacqueline and Lewis, E. B. (2004). Coming on Home Soon. New York: Putnam's.

Wright, Maureen and Hillenbrand, Will. (2009). Sleep, Big Bear, Sleep! New York: Two Lions.

Yolen, Jane and Sweet, Melissa. (2005). Baby Bear's Chairs. Orlando: Harcourt.

Yum, Hyewon. (2008). Last Night. Farrar, Straus and Giroux.

Zoboli, Giovanna and Di Giorgio, Mariachiara. (2017). Professional Crocodile. San Francisco: Chronicle Books.

Publisher's Note Springer Nature remains neutral with regard to jurisdictional claims in published maps and institutional affiliations. 